\title{
Analisis Potensi, Efektivitas Pemungutan, dan Kontribusi Pajak Hotel pada Pendapatan Asli Daerah
}

\author{
Putu Cahya Pramadya Utami ${ }^{1}$ \\ Fakultas Ekonomi dan Bisnis \\ Universitas Udayana, Indonesia
}

\author{
Ni Luh Supadmi² \\ Fakultas Ekonomi dan Bisnis \\ Universitas Udayana, Indonesia
}

\begin{abstract}
Surel : cahyautami82@gmail.com
ABSTRAK

Tujuan penelitian ini adalah untuk mengetahui besarnya potensi, efektivitas pemungutan, dan kontribusi pajak hotel di Kecamatan Kuta Selatan sebagai sumber PAD Kabupaten Badung. Penelitian ini dilakukan pada 54 hotel bintang, 50 hotel melati, dan 88 pondok wisata di Kecamatan Kuta Selatan dengan metode penentuan sampel simple random sampling. Pengumpulan data dilakukan melalui obervasi non partisipan dan survei. Teknik analisis yang digunakan adalah deskriptif kuantitatif. Berdasarkan hasil penelitian ditemukan besarnya potensi pajak hotel di Kecamatan Kuta Selatan yaitu sebesar 1.857.185.535.800 rupiah. Efektivitas pemungutan pajaknya sebesar 66 persen dan tergolong kurang efektif. Kontribusi pajak hotel di Kecamatan Kuta Selatan sebesar 10 persen dari penerimaan PAD Kabupaten Badung.
\end{abstract}

Kata Kunci: Potensi; Efektivitas; Kontribusi; PAD.

\section{Analysis of Potential, Effectiveness of Collection, and Hotel Tax Contribution to Local Own Revenue}

\section{ABSTRACT}

The purpose of this study was to determine the magnitude of the potential, effectiveness of collection, and hotel tax contributions in the District of South Kuta as a source of PAD in Badung Regency. This research was conducted at 54 star hotels, 50 jasmine hotels, and 88 tourist lodges in South Kuta District with the method of determining the sample of simple random sampling. Data collection was carried out through non-participant observation and surveys. The analysis technique used is quantitative descriptive. Based on the results of the study found the magnitude of the hotel tax potential in the District of South Kuta, amounting to 1,857,185,535,800 rupiah. The effectiveness of tax collection is 66 percent and classified as less effective. The contribution of hotel taxes in Kuta Selatan District is 10 percent of Badung Regency's PAD revenue.

Keywords: Potency; Effectiveness; Contribution; PAD.

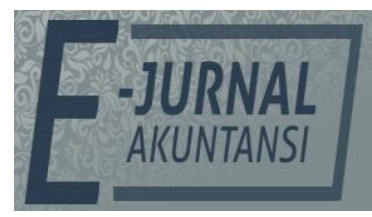

e-ISSN 2302-8556

Vol. 30 No. 12

Denpasar, Desember 2020

Hal. 3028-3040

DOI:

10.24843/EJA.2020.v30.i12.p03

PENGUTIPAN:

Utami, P.C.P. \& Supadmi, N.L. (2020). Analisis Potensi, Efektivitas Pemungutan, dan Kontribusi Pajak Hotel pada Pendapatan Asli Daerah. EJurnal Akuntansi, 30(12), 3028-3040

RIWAYAT ARTIKEL: Artikel Masuk: 26 Desember 2019 Artikel Diterima: 12 Nopember 2020

Artikel dapat diakses : https://ojs.unud.ac.id/index.php/Akuntansi/index 


\section{PENDAHULUAN}

Peraturan Pemerintah Republik Indonesia Nomor 55 Tahun 2016 tentang Ketentuan Umum dan Tata Cara Pemungutan Pajak Daerah, mengatakan bahwa Pajak Daerah adalah kontribusi wajib kepada daerah yang terutang oleh orang pribadi atau badan yang bersifat memaksa berdasarkan undang-undang, dengan tidak mendapatkan imbalan secara langsung dan digunakan untuk keperluan daerah bagi sebesar-besarnya kemakmuran rakyat. Pajak daerah merupakan salah satu sumber pendapatan daerah yang penting guna membiayai penyelenggaraan pemerintahan daerah dan pembangunan daerah untuk memantapkan otonomi daerah yang luas, nyata, dan bertanggung jawab. Otonomi daerah adalah upaya daerah pemberdayaan dalam membuat keputusan daerah lebih bebas untuk mengelola sumber daya yang dimiliki sesuai dengan potensi dan kepentingan daerah itu sendiri (Nasir et al., 2017). Pemerintah Daerah harus mampu menggali potensi PAD yang dimiliki secara maksimal, karena masing-masing daerah tidak semuanya terlaksana secara maksimal.

Menurut Undang-Undang Nomor 18 Tahun 1997 tentang Pajak Daerah dan Retribusi Daerah, pajak atas hotel disamakan dengan pajak restoran dengan nama pajak hotel dan restoran. Adanya perubahan Undang-Undang tentang Pajak Daerah dan Retribusi Daerah, dikeluarkannya Undang-Undang Nomor 34 Tahun 2000 tentang Pajak Daerah dan Retribusi Daerah yang diubah menjadi Undang-Undang Nomor 28 Tahun 2009 tentang Pajak Daerah dan Retribusi Daerah, pajak hotel dan restoran dipisahkan menjadi jenis pajak yang berdiri sendiri. Hal ini mengindikasikan besarnya potensi akan keberadaan pajak hotel dan pajak restoran dalam pembangunan suatu daerah. Penerimaan pajak hotel dan pajak restoran pada Pendapatan Asli Daerah tidak akan meningkat tanpa adanya sektor lain yang mendukung. Sektor lain yang dimaksud yaitu sektor pariwisata yang juga merupakan sektor potensial dikembangkan sebagai salah satu sumber Pendapatan Asli Daerah (Yuniarta, 2017).

Swami (2017) mengatakan bahwa pariwisata merupakan salah satu industri yang paling kompetitif dan terus berkembang di Indonesia. Salah satunya Kabupaten Badung merupakan salah satu kabupaten di Provinsi Bali yang memiliki banyak akomodasi wisata sehingga menjadi daerah tujuan utama pariwisata di Bali baik wisatawan domestik maupun wisatawan mancanegara (Dewi \& Merkusiwati, 2013). Kabupaten Badung memiliki potensi PAD dari sektor pariwisata, salah satunya dari pajak hotel. Konsekuensi pelaksanaan otonomi daerah menuntun Pemerintah Daerah meningkatkan sumber PAD, agar nantinya mampu membiayai penyelenggaraan pemerintah dan meningkatkan pelayanan kepada masyarakat. Industri perhotelan adalah salah satu sektor pariwisata dengan pertumbuhan tercepat di Indonesia (Walaba, 2016). Kabupaten Badung sebagai salah satu kabupaten yang ada di Provinsi Bali memiliki akomodasi hotel dan restoran yang cukup banyak. Perkembangan jumlah wajib pajak hotel selama lima tahun terakhir yang terdaftar pada Badan Pendapatan Daerah Kabupaten Badung disajikan pada Tabel 1, berikut.

Tabel 1, menunjukkan bahwa jumlah hotel di Kabupaten Badung terus mengalami peningkatan sejak tahun 2015 sampai dengan tahun 2018. Hal tersebut mengindikasikan pesatnya perkembangan sektor pariwisata di 
Kabupaten Badung. Banyaknya wisatawan yang berkunjung ke Kabupaten Badung serta meningkatnya minat pengusaha melakukan bisnis di bidang penginapan menyebabkan meningkatnya jumlah penyediaan fasilitas penginapan.

Tabel 1. Perkembangan Jumlah Wajib Pajak Hotel Kabupaten Badung Tahun 2014-2018

\begin{tabular}{lllll}
\hline \multirow{2}{*}{ Tahun } & \multicolumn{3}{c}{ Kategori } & \\
\cline { 2 - 4 } & Hotel & Hotel & Pondok & Jumlah \\
& Bintang & Melati & 999 & 1952 \\
\hline 2014 & 98 & 855 & 685 & 1298 \\
2015 & 155 & 458 & 775 & 1442 \\
2016 & 155 & 512 & 839 & 1533 \\
2017 & 155 & 539 & 885 & 1606 \\
2018 & 170 & 551 & & \\
\hline
\end{tabular}

Sumber: Data Penelitian, 2019

Menurut Peraturan Daerah Kabupaten Badung Nomor 15 Tahun 2011 Tentang Pajak Hotel, mengatakan bahwa pajak hotel merupakan salah satu sumber pendapatan asli daerah yang penting guna membiayai penyelenggaraan pemerintahan daerah berdasarkan prinsip demokrasi, pemerataan dan keadilan, peran serta masyarakat, dan akuntabilitas dengan memperhatikan potensi daerah. Potensi penerimaan pajak hotel dari tahun ke tahun rata-rata mengalami peningkatan. Peningkatan ini ditunjang dengan kondisi pariwisata daerah Kabupaten Badung yang merupakan daerah yang potensial untuk dibangun sarana dan prasarana penunjang kepariwisataan, sehingga semakin banyaknya tumbuh hotel baru penyedia kamar atau tempat penginapan yang berpengaruh positif terhadap penambahan penerimaan pajak melalui pajak hotel. Setiap daerah memiliki potensi dalam mengatur hak dan kewajibannya. Potensi tersebut dapat diketahui dari seberapa mampu suatu daerah setempat memberikan dan mengembangkan pembangunan demi kesejahteraan masyarakatnya (Yedikade \& Pesudo, 2019).

Pemerintah Daerah sebelum menentukan target pajak hotel harus menghitung potensi terlebih dahulu. Perhitungan potensi dilakukan permasingmasing wajib pajak hotel setelah mengetahui tarif kamar rata-rata tiap kamar hotel, jumlah kamar hotel, dan tingkat penghunian kamar hotel. Target dapat ditetapkan setelah mengetahui seberapa besar potensi pajak hotel sehingga penentuan besarnya target dapat mendekati atau sama dengan besarnya potensi. Langkah berikutnya menghitung tingkat efektivitas pemungutan penerimaan pajak hotel. Analisis efektivitas ini mutlak diperlukan guna mengukur seberapa besar pemungutan pajak hotel bisa direalisasikan. Semakin besar pemungutan pajak hotel, maka semakin besar pula kontribusi pajak hotel terhadap PAD Kabupaten Badung. Penelitian ini dilakukan di Kecamatan Kuta Selatan Kabupaten Badung yang merupakan daerah dengan jumlah hotel yang banyak dan sumber PAD terbesar di Kabupaten Badung dari pajak hotel dan pajak restoran. Semakin tinggi realisasi dibandingkan target, maka akan semakin tinggi tingkat efektivitas dari pemungutan pajak hotel tersebut. Perkembangan target dan realisasi penerimaan pajak hotel di Kabupaten Badung tahun 20142018 disajikan pada Tabel 2. 
Tabel 2. Perkembangan Realisasi dan Target Penerimaan Pajak Hotel di Kabupaten Badung Tahun 2014-2018

\begin{tabular}{|c|c|c|c|c|}
\hline Tahun & Target (Rp) & Realisasi (Rp) & $\begin{array}{l}\text { Efektivitas } \\
(\%)\end{array}$ & Kriteria \\
\hline 2014 & $1.260 .000 .000 .000,00$ & $1.454 .570 .508 .276,39$ & 115 & $\begin{array}{l}\text { Sangat } \\
\text { Efektif }\end{array}$ \\
\hline 2015 & 1.480.000.000.000,00 & 1.581.051.380.177,56 & 107 & $\begin{array}{l}\text { Sangat } \\
\text { Efektif }\end{array}$ \\
\hline 2016 & 1.644.235.157.506,54 & 1.774.637.210.687,55 & 108 & $\begin{array}{l}\text { Sangat } \\
\text { Efektif }\end{array}$ \\
\hline 2017 & 2.013.908.489.945,89 & 2.030.881.730.888,13 & 101 & $\begin{array}{l}\text { Sangat } \\
\text { Efektif }\end{array}$ \\
\hline 2018 & 3.412.502.820.507,34 & 2.236.311.260.005,09 & 66 & $\begin{array}{l}\text { Kurang } \\
\text { Efektif }\end{array}$ \\
\hline
\end{tabular}

Sumber: Data Penelitian, 2019

Berdasarkan Tabel 2, tingkat efektivitas pemungutan pajak hotel di Kabupaten Badung tahun 2014 hingga 2017 memiliki angka rata-rata lebih dari 100 persen yang berarti bahwa realisasi lebih besar dari target yang ditetapkan oleh Pemerintah Daerah, namun di tahun 2018 efektivitasnya kurang dari 100 persen yaitu sebesar 66 persen. Hal tersebut mengindikasikan adanya potensi yang belum digali secara maksimal. Di lihat dari target dan realisasinya bahwa efektivitas pemungutan pajak semakin menurun, bahkan di tahun 2018 tergolong kurang efektif. Semakin tinggi potensi pajaknya belum tergali, maka pemungutan pajak semakin tidak efektif. Hal tersebut akan berdampak pada kontribusinya terhadap PAD yang semakin menurun.

Dalam penelitian ini dilakukan kajian tentang potensi pajak hotel yang ada di Kecamatan Kuta Selatan Kabupaten Badung karena berdasarkan data yang ada terdapat permasalahan yang krusial yaitu adanya potensi pajak hotel yang belum digali secara maksimal, dilihat dari efektivitas pemungutan pajak hotel di tahun 2018 kurang efektif hanya sebesar 66 persen. Potensi yang sebenarnya dimiliki dari pajak hotel sangat penting diketahui untuk menetapkan target dan mengetahui besarnya kontribusi pajak hotel, sehingga dapat menjadi dasar dan panduan dalam pelaksanaan program-program peningkatan penerimaan daerah terutama dari sisi pajak. Pemerintah harus melakukan perbaikan dan penyempurnaan di dalam bidang pemungutan pajak daerah dan di kelola secara efektif dan efisien agar penerimaan pemerintah terus meningkat, sehingga dapat memperlancar pembangunan (Sulastri \& Nugraha, 2019).

Penelitian mengenai analisis potensi, efektivitas pemungutan, dan kontribusi pajak hotel pada Pendapatan Asli Daerah telah banyak dilakukan oleh peneliti terdahulu. Penelitian yang dilakukan oleh Benita, dkk (2019) mengenai analisis potensi dan realisasi penerimaan pajak hotel di Kabupaten Pemalang, dapat disimpulkan bahwa potensi pajak hotel Kabupaten Pemalang memiliki selisih yang sangat besar dengan realisasi penerimaan pajak hotel. Meskipun, potensi pajak hotel Kabupaten Pemalang setiap tahunnya mengalami peningkatan dan yang terbesar ialah tahun 2018 sebesar 3.205734.770 rupiah. Tingkat efektivitas penerimaan pajak hotel setiap tahunnya meningkat tapi persentasenya masih rendah. Tingkat efektivitas tertinggi terjadi pada tahun 2018 yaitu sebesar 15,70 persen. 
Penelitian yang dilakukan oleh Suleman (2018) tentang kontribusi pajak hotel terhadap PAD Dispenda Kabupaten Bogor, disimpulkan bahwa potensi pajak hotel terhadap PAD tahun 2014 sebesar 0,83 persen sedangkan pada tahun 2015 potensi pajak hotel mengalami penurunan dari tahun sebelumnya yaitu sebesar 0,76 persen, dan pada tahun 2016 pajak hotel mengalami kenaikan kembali dari tahun sebelumnya yaitu sebesar 0,95 persen. Realisasi di tahun 2014 sebesar 44.871.730.571 rupiah melebihi dari target yang telah ditentukan oleh Dinas Pendapatan Daerah Kabupaten Bogor yaitu sebesar 43.115.356.000 rupiah. Pada tahun 2015 realisasi pajak hotel sebesar 46.272.337.687 rupiah, melebihi dari target yang ditentukan oleh Dispenda Kabupaten Bogor yaitu sebesar 45.932.246.000 rupiah. Pada tahun 2016 realisasi pajak hotel sebesar 57.210.871.840 rupiah, melebihi target yaitu sebesar 53.617.308.000 rupiah.

Pada penelitian Yuliartini \& Supadmi (2015) yang berjudul efektivitas pemungutan pajak hotel dan restoran pada Pemerintah Daerah Kota Denpasar, disimpulkan bahwa rata-rata tingkat efektivitas pemungutan pajak hotel dan restoran di Kota Denpasar dari tahun 2009-2013 yang diukur dengan rasio efektivitas adalah sebesar 113,54 persen dan tergolong dalam kategori sangat efektif. Tingkat kontribusi pemungutan pajak hotel dan restoran pada PAD di tahun 2009 dan 2010 digolongkan dalam kategori baik dengan tingkat kontribusi masing-masing sebesar 47,01 persen dan 44,33 persen, di tahun 2011 digolongkan dalam kategori cukup baik dengan tingkat kontribusi sebesar 30,95 persen, dan di tahun 2012 dan 2013 digolongkan dalam kategori sedang dengan tingkat kontribusi masing-masing sebesar 29,33 persen dan 25,81 persen. Rata-rata tingkat kontribusi pemungutan pajak hotel dan restoran selama lima tahun terakhir adalah sebesar 32,27 persen dan digolongkan dalam kategori cukup baik.

\section{METODE PENELITIAN}

Penelitian ini hanya memberikan informasi mengenai data yang diamati dan tidak bertujuan menguji hipotesis. Penelitian hanya terbatas pada persentase yang di dapat dari data kuantitatif yang berkaitan dengan penerimaan pajak hotel di Kecamatan Kuta Selatan Kabupaten Badung. Dari hasil perhitungan persentase tersebut, penulis menggunakan pemikiran yang logis untuk menggambarkan dan menjelaskan secara mendalam tentang keadaan yang sebenarnya, kemudian ditarik suatu kesimpulan sehingga dapat diperoleh suatu penyelesaian atas permasalahan yang penulis teliti.

Lokasi penelitian ini adalah pada hotel bintang, hotel melati, dan pondok wisata yang ada di Kecamatan Kuta Selatan. Kecamatan Kuta Selatan terdiri dari enam Desa/Kelurahan yakni Jimbaran, Ungasan, Pecatu, Kutuh, Benoa, dan Tanjung Benoa. Penelitian ini dilakukan untuk mengetahui proyeksi potensi pajak hotel sebagai sumber Pendapatan Asli Daerah (PAD) Kabupaten Badung. Lokasi penelitian dipilih karena di Kecamatan Kuta Selatan memiliki jumlah hotel yang cukup banyak, objek wisata yang indah, dengan kondisi seperti itu kemungkinan memiliki potensi pajak hotel yang cukup besar.

Populasi dalam penelitian ini adalah seluruh wajib pajak hotel yang ada di Kecamatan Kuta Selatan Kabupaten Badung, diantaranya hotel bintang sebanyak 63, hotel melati sebanyak 57, dan pondok wisata sebanyak 112 yang 
didapat pada Direktori Dinas Pariwisata Kabupaten Badung. Teknik pengambilan sampel yang digunakan dalam penelitian ini menggunakan rumus Slovin yaitu:

$n=\frac{N}{\left(1+N e^{2}\right)}$

Keterangan :

$\mathrm{n}=$ ukuran sampel

$\mathrm{N}=$ ukuran populasi (jumlah wajib pajak)

$\mathrm{e}=$ persentase kelonggaran ketidakpastian karena kesalahan pengambilan sampel yang masih dapat ditolerir yaitu 5 persen.

Jumlah populasi berdasarkan data dari Direktori Dinas Pariwisata Kabupaten Badung menyebutkan bahwa jumlah wajib pajak hotel pada tahun 2019, yaitu hotel bintang berjumlah 63, hotel melati berjumlah 57, dan pondok wisata berjumlah 112 .

Berdasarkan perhitungan tersebut, maka sampel dalam penelitian ini adalah hotel bintang berjumlah 54 , hotel melati berjumlah 50 , dan pondok wisata berjumlah 88. Teknik pengambilan sampel dalam penelitian ini menggunakan teknik probability sampling. Probability sampling dibagi menjadi dua, yaitu non probability sampling method dan probability sampling method. Teknik analisis data yang digunakan dalam penelitian ini adalah metode analisis deskriptif dengan menggunakan rumus potensi pajak hotel, efektivitas pajak hotel, dan kontribusi pajak hotel. Pemilihan sampel dilakukan dengan cara simple random sampling, sehingga data penelitian yang ada dapat menggambarkan keadaan populasi yang sebenarnya dengan memberikan kesempatan yang sama tanpa memperhatikan tingkatan atau kedudukan masyarakat (strata) kepada populasi untuk dijadikan sampel.

\section{HASIL DAN PEMBAHASAN}

Sampel penelitian ini adalah jumlah wajib pajak hotel di Kecamatan Kuta Selatan yang terdaftar pada Direktori Dinas Pariwisata Kabupaten Badung yaitu hotel bintang sebanyak 54, hotel melati sebanyak 50, dan pondok wisata sebanyak 88 . Karakteristik sampel berdasarkan klasifikasi hotel disajikan pada Tabel 3.

\section{Tabel 3. Klasifikasi Hotel}

\begin{tabular}{lll}
\hline $\begin{array}{l}\text { Karakteristik } \\
\text { Responden }\end{array}$ & Keterangan & Jumlah \\
\hline Hotel Bintang & Hotel Bintang 1 & - \\
& Hotel Bintang 2 & 1 \\
& Hotel Bintang 3 & 6 \\
& Hotel Bintang 4 & 20 \\
& Hotel Bintang 5 & 27 \\
Hotel Melati & - & 50 \\
Pondok Wisata & - & 88 \\
\hline
\end{tabular}

Sumber: Data Penelitian, 2019

Data klasifikasi hotel ini peneliti dapatkan dari Direktori Dinas Pariwisata Kabupaten Badung tahun 2018. Dalam penelitian ini, peneliti tidak meneliti rumah kos karena pada Direktori Dinas Pariwisata Kabupaten Badung 2018 
peneliti tidak menemukan data wajib pajak hotel untuk rumah kos yang ada di Kecamatan Kuta Selatan Kabupaten Badung.

Potensi pajak hotel dapat diartikan sebagai kekuatan sebenarnya dari pajak hotel. Pemungutan pajak hotel yang diawali dengan perhitungan potensi yang sebenarnya untuk mengetahui seberapa besar jumlah pajak yang seharusnya bisa dipungut dari hotel tersebut. Perhitungan potensi sangat membantu dalam mengefektifkan dan mengoptimalisasi pemungutan pajak daerah dari pajak hotel. Jumlah wajib pajak hotel dan jumlah kamar di Kecamatan Kuta Selatan Kabupaten Badung 2019 disajikan pada Tabel 4, berikut. Tabel 4. Jumlah Hotel dan Jumlah Kamar Hotel di Kecamatan Kuta Selatan Kabupaten Badung 2019

\begin{tabular}{cccc}
\hline No & Jenis Hotel & $\begin{array}{c}\text { Jumlah } \\
\text { Hotel }\end{array}$ & $\begin{array}{c}\text { Jumlah } \\
\text { Kamar }\end{array}$ \\
\hline 1 & Hotel Bintang 2 & 1 & 28 \\
2 & Hotel Bintang 3 & 6 & 471 \\
3 & Hotel Bintang 4 & 20 & 2.801 \\
4 & Hotel Bintang 5 & 27 & 9.418 \\
5 & Hotel Melati & 50 & 3.169 \\
6 & Pondok Wisata & 88 & 318 \\
& Jumlah & 192 & 16.205 \\
\hline
\end{tabular}

Sumber: Data Penelitian, 2019

Potensi pajak hotel yang sebenarnya dimiliki pada setiap klasifikasi hotel dapat dihitung setelah mengetahui tarif kamar rata-rata tiap kamar hotel dengan menggunakan rumus perhitungan potensi pajak hotel dengan cara mengalikan jumlah kamar dengan tarif kamar rata-rata, jumlah hari dalam setahun, tingkat penghunian kamar, dan tarif pajak hotel sebesar 10 persen. Perhitungan potensi dilakukan pada masing-masing wajib pajak hotel. Hasil perhitungan potensi pajak hotel di Kecamatan Kuta Selatan Kabupaten Badung tahun 2019 sebesar 1.857.185.535.800 rupiah dari 192 hotel dengan jumlah kamar sebanyak 16.205.

Dalam menetapkan target yang kemungkinan dapat direalisasikan dapat dilakukan dengan tiga skenario yaitu skenario pesimis, moderat, dan optimis. Cara perhitungan yang dapat dilakukan untuk mendapatkan kemungkinan target pajak hotel di Kecamatan Kuta Selatan Kabupaten Badung yang dapat direalisasikan yaitu dengan cara mengalikan potensi pajak hotel dengan suatu persentase bobot yaitu menggunakan rata-rata tingkat hunian kamar setelah dicari nilai minimum, netral, dan maksimumnya.

Tabel 5. Kemungkinan Target Pajak Hotel di Kecamatan Kuta Selatan dapat ditetapkan oleh Pemerintah Kabupaten Badung

\begin{tabular}{ll}
\hline Skenario & $\begin{array}{l}\text { Kemungkinan Target } \\
\text { Pajak Hotel } \\
(\mathrm{Rp})\end{array}$ \\
\hline Pesimis & 928.592 .767 .900 \\
Moderat & 1.117 .406 .630 .706 \\
Optimis & 1.857 .185 .535 .800 \\
\hline
\end{tabular}

Sumber: Data penelitian, 2019

Berdasarkan Tabel 5, target pajak hotel yang dapat ditetapkan oleh Pemerintah Kabupaten Badung adalah target paling kecil atau kondisi pesimis sebesar 928.592.767.900 rupiah, target netral atau moderat sebesar 
1.117.406.630.706 rupiah, dan besarnya target pajak hotel yang paling maksimum atau kondisi optimis yaitu sebesar 1.857.185.535.800 rupiah. Pemerintah dalam menetapkan target pajak hotel dapat mendekati atau sebesar potensinya, disesuaikan dengan jumlah kunjungan wisatawan ke Kecamatan Kuta Selatan Kabupaten Badung yang sangat berpengaruh pada peningkatan potensi pajak hotel. Potensi pajak hotel yang tinggi bila tidak diimbangi dengan penetapan target yang tidak sesuai, maka akan mempengaruhi perilaku pemungut pajak hotel. Hal tersebut mendukung theory planned of behavior yaitu jika di Kecamatan Kuta Selatan sebenarnya memiliki potensi pajak hotel yang tinggi, namun target yang ditetapkan lebih rendah bahkan realisasinya tidak mencapai target berarti masih ada potensi yang belum tergali. Hal tersebut mengindikasikan perlu peningkatan perilaku pemungut pajak hotel dalam menjalankan tugas pemungutan untuk meningkatkan kepatuhan wajib pajak. Pemerintah dapat melakukan upaya dengan memberikan sanksi tegas bagi wajib pajak yang melanggar peraturan perundang-undangan yang berlaku, ini mengkonfirmasi teori normative beliefs dan teori regulasi. Pemerintah juga dapat memberikan sosialisasi kepada wajib pajak bahwa pajak merupakan hak yang dimiliki oleh pemerintah daerah dimana wajib pajak hotel mempunyai kewajiban untuk membayar pajak yang telah dipungut.

Efektivitas pemungutan pajak hotel dihitung setelah mengetahui besarnya realisasi dan target pajak hotel di Kecamatan Kuta Selatan Kabupaten Badung. Besarnya realisasi atau target pajak hotel di Kecamatan Kuta Selatan dapat dihitung dengan memproporsionalkan jumlah kamar hotel di Kecamatan Kuta Selatan dengan jumlah kamar hotel di Kabupaten Badung dikalikan realisasi atau target pajak hotel di Kabupaten Badung. Jumlah kamar hotel di Kecamatan Kuta Selatan yaitu sebesar 16.205 kamar, dibandingkan dengan jumlah kamar hotel di Kabupaten Badung sebesar 67.003 kamar. Besarnya realisasi pajak hotel di Kecamatan Kuta Selatan yang didapatkan setelah diproposionalkan yaitu sebesar 540.862.707.168 rupiah dan target pajak hotel di Kecamatan Kuta Selatan yaitu sebesar 825.330.331.572 rupiah.

Dari hasil perhitungan tersebut, maka didapatkan nilai rasio efektivitas pemungutan pajak hotel di Kecamatan Kuta Selatan Kabupaten Badung sebesar 66 persen yang berarti bahwa pemungutan pajaknya kurang efektif karena menunjukkan angka rata-rata kurang dari 100 persen. Pemungutan pajak yang tidak efektif dapat disebabkan karena kurangnya pengawasan, hal tersebut mendukung theory of planned behavior yaitu control beliefs dari Badan Pendapatan Daerah Kabupaten Badung sehingga masih ada wajib pajak yang melanggar peraturan perundang-undangan yang berlaku dengan tidak melaporkan pajak yang sebenarnya harus dibayarkan. Adanya pengawasan yang ketat terhadap wajib pajak dalam pelaksanaan penyetoran pemungutan pajak, maka kecil kemungkinan pemungutan pajaknya tidak efektif.

Besarnya kontribusi pajak hotel di Kecamatan Kuta Selatan pada Pendapatan Asli Daerah Kabupaten Badung dapat diketahui dengan cara membandingkan realisasi penerimaan pajak hotel di Kecamatan Kuta Selatan dengan realisasi penerimaan PAD Kabupaten Badung. Besarnya realisasi pajak hotel di Kecamatan Kuta Selatan yaitu sebesar 540.862.707.168 rupiah dan realisasi penerimaan PAD Kabupaten Badung yaitu sebesar 5.272.457.400.000 
rupiah. Dari hasil perhitungan tersebut maka besarnya kontribusi Kecamatan Kuta Selatan pada PAD Kabupaten Badung yaitu sebesar 10 persen yang berarti kontribusinya kurang. Hal ini di duga adanya potensi lain yang belum tergali secara maksimal akibat realisasi pajak hotel di Kecamatan Kuta Selatan lebih kecil dari target pajak hotel di Kecamatan Kuta Selatan.

Kecilnya hasil kontribusi terhadap PAD, dapat dikatakan bahwa sebagian besar wajib pajak hotel yang ada di Kecamatan Kuta Selatan Kabupaten Badung belum maksimal dalam melaporkan pajaknya. Hal tersebut mengkonfirmasi teori regulasi, dimana wajib pajak dinilai belum sepenuhnya mentaati peraturan perundang-undangan yang berlaku khususnya dalam memenuhi kewajiban perpajakannya. Upaya yang dapat dilakukan pemerintah yaitu dengan mengawasi secara lebih ketat dalam pemungutan pajak di setiap hotel dengan pemeriksaan lapangan, memberikan sanksi hukum apabila ada wajib pajak yang melanggar, dan memberikan kesadaran dengan sosialisasi bagi wajib pajak agar melaporkan kewajiban pajaknya dengan benar.

\section{SIMPULAN}

Penelitian ini diharapkan dapat memberikan kontribusi mengenai teori planned of behavior dan teori regulasi dalam menjelaskan potensi, efektivitas pemungutan, dan kontribusi pajak hotel pada Pendapatan Asli Daerah di Kecamatan Kuta Selatan Kabupaten Badung. Hasil penelitian ini mengatakan besarnya potensi pajak hotel belum digali secara maksimal. Hal tersebut dibuktikan karena realisasi pajak hotel yang lebih kecil dari target yang ditetapkan sehingga tingkat efektivitas pemungutan pajak hotelnya menjadi kurang efektif dan juga kontribusinya kurang. Wajib pajak hotel masih banyak yang belum mematuhi peraturan yang sudah ditetapkan oleh pemerintah dengan tidak melaporkan kewajiban pajak yang sebenarnya dapat dilihat dari besarnya tunggakan pajak. Hal tersebut sangat mempengaruhi besarnya Pendapatan Asli Daerah yang diterima Kabupaten Badung. Penelitian ini memberikan implikasi bagi Pemerintah Kabupaten Badung khususnya Badan Pendapatan Daerah Kabupaten Badung sebagai pertimbangan mengenai upaya meningkatkan tingkat kepatuhan wajib pajak hotel dalam membayar kewajiban pajaknya.

Potensi pajak hotel di Kecamatan Kuta Selatan Kabupaten Badung dalam kondisi optimis sebesar 1.827.206.706.177 rupiah, kondisi moderat (netral) sebesar 1.117.406.630.706 rupiah, dan kondisi pesimis (kecil) sebesar 928.592.767.900 rupiah. Efektivitas pemungutan pajak hotel di Kecamatan Kuta Selatan Kabupaten Badung tergolong kurang efektif karena hanya sebesar 66 persen. Kontribusi pajak hotel Kecamatan Kuta Selatan pada penerimaan Pendapatan Asli Daerah Kabupaten Badung sebesar 10 persen dan termasuk kriteria kurang. Bagi wajib pajak yang tidak memenuhi kewajiban perpajakannya harus diberikan sanksi sesuai dengan peraturan perundang-undangan yang berlaku. Mengefektifkan pemungutan pajak dapat dilakukan dengan cara pemeriksaan lapangan.

Keterbatasan dalam penelitian ini yaitu peneliti tidak menghitung besarnya pajak terutang untuk food $\mathcal{E}$ beverage yang disediakan di restoran yang ada di hotel, ruang pertemuan, dan jasa hotel lainnya untuk menghitung potensi pajak hotel di Kecamatan Kuta Selatan Kabupaten Badung. Hal ini diakibatkan 
karena keterbatasan peneliti dalam memperoleh data. Penelitian ini juga tidak menghitung potensi pajak hotel untuk rumah kos yang ada di Kecamatan Kuta Selatan. Bagi peneliti selanjutnya, diharapkan dapat memperoleh data objek pajak yang kurang dari penelitian ini yaitu rumah kos sehingga perhitungan potensi pajak hotel mencerminkan potensi yang sesungguhnya.

\section{REFERENSI}

Ajzen, I. (2006). Constructing a TpB Questionnaire. Hepatology (Baltimore, Md.), 49(4), 1335-1374. https://doi.org/10.1002/hep.22759 (diakses pada 5 September 2019

Anggraini, N. L. P., Jantje, J. T., dan Stanley, K. W. (2018). Analisis Efektivitas Pemungutan Pajak Hotel Dan Pajak Restoran Serta Kontribusinya Terhadap Pendapatan Asli Daerah Kota Tomohon. Jurnal Riset Akuntansi Going Concern, 13(4), 2018, 262-271.

Badan Pendapatan Daerah/Pasedahan Agung Kabupaten Badung. (2019). https://badungkab.go.id/instansi/bapenda/home

Benita, N., Adechandra, D., \& Pesudo, A. (2019). Analisis Potensi dan Realisasi Penerimaan Pajak Hotel di Kabupaten Pemalang. International Journal of $\begin{array}{llll}\text { Social Science } & \text { Bnd }\end{array}$ https://doi.org/10.23887/ijssb.v3i2.17588 (diakses tanggal 7 Agustus 2019)

Dewi, A., \& Merkusiwati, N. (2013). Analisis Tingkat Kepatuhan Wajib Pajak Atas Pemenuhan Kewajiban Pajak Hotel Dan Restoran Di Kabupaten Badung Tahun 2011. E-Jurnal Akuntansi, 4(1), 110-127.

Direktori Dinas Pariwisata Provinsi Bali. (2018). Bali Government Tourism Office. http://www.tourism.baliprov.go.id

Isnaani, D. (2017). Analisis penerimaan pajak restoran dan pajak hotel sebagai sumber pendapatan asli daerah. Jurnal Universitas Muhammadiyah Surakarta

Kecamatan Kuta Selatan Dalam Angka. (2019). https:/ / badungkab.bps.go.id/publication/2019/09/26/77ca3af3f67d1b cd7c387d77/kecamatan-kuta-selatan-dalam-angka-2019.html (diakses tanggal 28 September 2019)

Kesek, F. (2013). Efektivitas Dan Kontribusi Penerimaan Pajak Parkir Terhadap Pendapatan Asli Daerah Kota Manado. Jurnal Riset Ekonomi, Manajemen, Bisnis Dan Akuntansi, 1(4), 1922-1933.

Kononov, A. Y., Gomilevskaya, G. A., \& Schur, V. V. (2019). Infrastructure and Personnel Provisioning for Innovation Activity of Hotel Facilities. International Scientific Conference "Far East Con" (ISCFEC), 47(2018), 752756. https://doi.org/10.2991/iscfec-18.2019.183 (diakses tanggal 9 Agustus 2019)

Lamia, A. A., Saerang, D. P. E., Wokas, H. R. N., Akuntansi, J., Ekonomi, F., \& Bisnis, D. (2015). Analisis Efektivitas Dan Kontribusi Pemungutan Pajak Restoran, Pajak Reklame, Dan Pajak Penerangan Jalan Pada Pendapatan Asli Daerah Kabupaten Minahasa Utara. Jurnal Berkala Ilmiah Efisiensi, 15(05), https://ejournal.unsrat.ac.id/index.php/jbie/article/viewFile/10474/1 
0060 (diakses tanggal 9 Agustus 2019)

Lesmana, D., Panjaitan, D., \& Maimunah, M. (2018). Tax Compliance Ditinjau dari Theory of Planned Behavior (TPB): Studi Empiris Pada Wajip Pajak Orang Pribadi dan Badan yang Terdaftar Pada KPP di Kota Palembang. Jurnal Infestasi, 13(2), 354. https://doi.org/10.21107/infestasi.v13i2.3514 (diakses pada 4 September 2019)

Mas, I. G. A. M. A., \& Pratiwi, A. (2014). Pengaruh Kesadaran Wajib Pajak, Kualitas Pelayanan, Kondisi Keuangan, dan Persepsi Tentang Sanksi Perpajakan Pada Kepauhan Wajib Pajak Reklame Di Dinas Pendapatan Kota Denpasar Fakultas Ekonomi Dan Bisnis Universitas Udayana. E Journal Akuntansi Udayana, 1, 139-153.

Mitha Pratiwi, N. P., \& Merkusiwati, N. K. L. A. (2019). Pengaruh Kualitas Pelayanan, Kewajiban Moral, Sanksi Pajak dan Tapping Box pada Kepatuhan Wajib Pajak Hotel. E-Jurnal Akuntansi, 26(32), 1357. https://doi.org/10.24843/eja.2019.v26.i02.p19 (diakses pada 6 September 2019)

Nasir, A., Basri, Y. M., Kamaliah, \& Muda, I. (2017). Effectiveness of potential tax region as the real local revenue sources in riau coastal area. International Journal of Economic Research, 14(12), 313-324. (diakses tanggal 11 Agustus 2019)

Peraturan Daerah Kabupaten Badung Nomor 15 Tahun 2011 Tentang Pajak Hotel.

Peraturan Daerah Provinsi Daerah Khusus Ibu Kota Jakarta Nomor 9 Tahun 1998 Tentang Pajak Hotel dan Restoran.

Peraturan Pemerintah Nomor 55 Tahun 2016 Tentang Ketentuan Umum dan Tata Cara Pemungutan Pajak Daerah.

Purnamawati, I. G. A., \& Nursansiwi, D. A. (2018). Analysis of Taxpayer Annual Reporting of Taxpayer Manually To the Tax Revenue Target in Buleleng Regency. International Journal of Social Science and Business, 2(1), 20152017. https://doi.org/10.23887/ijssb.v2i1.12703 (diakses tanggal 10 Agustus 2019)

Puspita, A. F. (2016). Analisis Penetapan Target Penerimaan Pajak Daerah ( Studi Pada Dispenda Kota Malang ). Jurnal Administrasi Dan Bisnis, 10(1), 2538. jadbis.polinema.ac.id/index.php/adbis/article/download/8/4 (diakses tanggal 8 Oktober 2019)

Putri, R. B. A. W. P., Kumadji, S., \& Darono, A. (2014). Analisis Penerimaan Pajak Hotel Pajak Restoran Pajak Hiburan Sebagai Sumber Pendapatan Asli Daerah (Studi Kasus Dinas Pendapatan Daerah Kota Malang). Jurnal Perpajakan, 3(1), 1-8

Sita Irfani, M., Probowulan, D., \& Pramono, D. E. (2019). Efektivitas, Daya Pajak dan Kontribusi Pajak Kendaraan Bermotor Tahun 2013-2017 di UPT Pengelolaan Pendapatan Daerah Provinsi Jawa Timur Bondowoso. International Journal of Social Science and Business, 3(2), 104. https://doi.org/10.23887/ijssb.v3i2.17583 (diakses tanggal 8 Agustus 2019)

Sitompul, A., Syahnur, S., \& Ichsan, C. (2014). The Role of Hotel and Restaurant Taxes and Its Effect on Banda Aceh'S Local Own Source Revenue. Aceh 
International Journal of Social Sciences, 3(1), 45-57.

Stigler, G. J. (1971). The theory regulation of economic. The Bell Journal of Economics and Management Science, 2(1), 3-21. https://doi.org/10.2307/3003160 (diakses tanggal 9 Agustus 2019)

Suciadi, Arif. (2014). Tingkat Kontribusi dan Efektivitas Pajak Hotel dan Restoran Pada Pendapatan Asli Daerah (PAD) Kabupaten Malang Jawa Timur. Jurnal Ilmiah Mahasiswa FEB Universitas Brawijaya. https://jimfeb.ub.ac.id/index.php/jimfeb/article/view/1301 (diakses tanggal 6 Agustus 2019)

Sugiarto, Yayan, Ananta Budhi Danurdara, and Nur Rofi. (2015). Analisis Potensi Penerimaan Pajak Hotel di Kabupaten Pemalang Jawa Tengah. Jurnal Barista, Volume 2, Nomor 1 (Juli 2015): 1-15.

Sulastri, L., \& Nugraha, P. (2019). Supervision of Hotel and Restaurant Tax Learning To Improve Regional Original Income (PAD) Sumedang District. Journal of Economic Empowerment Startegy, Vol 02(01), 13-23.

Suleman, D. (2018). Kontribusi Pajak Hotel Terhadap (Pad) Dispenda Kabupaten Bogor. Moneter - Jurnal Akuntansi Dan Keuangan, 5(1), 57-62. http://ejournal.bsi.ac.id/ejurnal/index.php/moneter/article/view/276 3/2189 (diakses pada 5 September 2019)

Swami, S. G. A. (2017). Impact of GST on Travel and Tourism Industry. International Journal of Science and Research (IJSR), 6(11), 973-976. https://www.ijsr.net/archive/v6i11/ART20177994.pdf (diakses tanggal 9 Agustus 2019)

Tarmizi, H. B., Daulay, M and Muda, I. (2017). Impact of The Economic Growth and Acquisition of Land to The Construction Cost Index in North Sumatera. IOP Conference Series : Materials Science and Engineering. 180.

Agustus 2019)

doi: 10.1088/1757-899X/180/1/012004 (diakses tanggal 11

Undang-Undang Republik Indonesia Nomor 18 Tahun 1997 Tentang Pajak Daerah dan Retribusi Daerah.

Undang-Undang Republik Indonesia Nomor 33 Tahun 2004 Tentang Perimbangan Keuangan Antara Pemerintah Pusat dan Pemerintahan Daerah.

Undang-Undang Republik Indonesia Nomor 28 Tahun 2009 Tentang Pajak Daerah dan Retribusi Daerah.

Undang-Undang Republik Indonesia Nomor 34 Tahun 2000 Tentang Pajak Daerah dan Retribusi Daerah.

Walaba, R. M. P. (2016). Effectiveness of Staff Training on the Performance of Hotels in Kisumu City, Kisumu County, Kenya. International Journal of Science and Research (IJSR), 5(12), 2129-2133. https://doi.org/10.21275/ART20162773 (diakses tanggal 10 Agustus 2019)

Yahya, I., Torong, M. Z. B., \& Muda, I. (2017). Influence behavior in legislature budget development of regions in the province of Aceh and North Sumatra. International Journal of Economic Research, 14(20), 255-267. (diakses tanggal 11 Agustus 2019) 
Yedikade, D. E., \& Pesudo, D. A. A. (2019). Potensi dan Realisasi Pajak Kendaraan Bermotor Kabupaten Polewali Mandar. International Journal of Social Science and Business, 3(2), 154. https://doi.org/10.23887/ijssb.v3i2.17636 (diakses tanggal 8 Agustus 2019)

Yuliartini, P. I., \& Supadmi, N. L. (2015). Efektivitas Pemungutan Pajak Hotel Dan Restoran Pada Pemerintah Daerah Kota Denpasar. E Journal Akuntansi Udayana, 2, 489-502.

Yuniarta, G. A. (2017). The Relations of Total Tourists Visit on Operational Cost At Stars Hotel in Buleleng District. International Journal of Social Science and Business, 1(4), 229. https://doi.org/10.23887/ijssb.v1i4.12532 (diakses tanggal 10 Agustus 2019) 